\title{
Variable Rotational Speed Control System of Sewage Pumping Station
}

\author{
E. Szychta \& L. Szychta \\ UTP University of Science and Technology in Bydgoszcz, Bydgoszcz, Poland
}

\begin{abstract}
Cascade and variable rotational speed control systems of sewage pumping stations are compared in this article. The range of pump efficiency variations and potential for breakdowns are adopted as criteria. A pumping station including two or three pumps is analysed. A control system at a variable rotational speed and maximum sewage level is presented. Properties of a cascade control system and a system at maximum head of sewage are compared using the example of any pump performance chart.
\end{abstract}

\section{INTRODUCTION}

A cascade control system of a sewage pumping station is widely known and applied. This is primarily decided by simplicity of the system. No impact on the pumping system is present other than the function of pump switch on and off. This is enabled by drive systems of induction motors using frequency converters.

A dry well sewage pumping station (pumps operating in a dry well separate from a sewage tank) is illustrated in Figure 1. A suction manifold is immersed in a storage reservoir with capacity $Q_{x}$, where sewage comes. The pump operates to change the sewage level from a minimum head $H_{z \min }$ to a maximum of $H_{z \max }$. Sewage is pumped through a discharge line at capacity $Q_{o}$ to a sewage receiving body. As sewage flows, dynamic pressure losses $\Delta H=a \mathrm{Q}_{0}{ }^{2}$ are generated. Figure 1 shows head of pressure $H_{t}$ across the pressure manifold meets the dependence $[3,5,9,14]$ :

$$
H_{t}=H_{s t}+a Q_{o}^{2}+H_{z n}
$$

The following equation is also true:

$$
H_{t}=H+H_{z n}
$$

where:

$H_{z n}$ - head of sewage at suction pipe relative to the pump's horizontal axis (Fig. 1).



Figure 1. An example of head of pressure distribution for a sewage pumping station $[8,12]$ 




Figure 2. Pump flow characteristic $p_{1}$ relative to the standard curve $r_{1}$ of a pumping system; $H[\mathrm{~m}], Q[1 / \mathrm{s}]$ [13]

(2) implies the greater $H_{z n}$, the lower the head of pump $H$. This reduces demand for electricity from the pump electric motor. Figure 2 implies the pumping station's capacity $Q_{2}$ is the same for operating points $\mathrm{W}_{2}$ and $\mathrm{W}_{2}^{*}$. Head $\mathrm{H}_{2}{ }^{*}$ of the pump is greater for the point $\mathrm{W}_{2}{ }^{*}$, which means a greater demand for electricity. At point $\mathrm{W}_{2}{ }^{*}$, the pump operates at a rated rotational speed along the flow characteristic $p_{1}$. Operation along the flow characteristic $p_{2}$ at a lower rotational speed $n<n_{\mathrm{N}}$ reduces consumption of electric power. Pump operation should be controlled in such a way as to generate maximum sewage levels in the storage tank in order to arrive at the foregoing effect $[6,7,10,11]$.

\section{COMPARATIVE ANALYSIS OF CONTROL SYSTEMS}

Sewage flows into a pumping station stochastically. For the purposes of comparative analysis, certain conditions ensuring correct function of the entire pumping system authors assumed:

- Sewage cannot be allowed to putrefy if it comes slowly,

- Minimum pumping station efficiency should provide for a rate of sewage flow across the pressure manifold sufficient for particulate movement,

- Maximum pumping station efficiency should not allow for an excessive rate of sewage flow, which would produce high dynamic pressure losses,

- Range of pump efficiency variations should follow the manufacturer's recommendations in order to meet the criterion of reliable operation (Fig. 3),

- Other conditions characteristic for a medium transported and ensuring safe and reliable pumping.

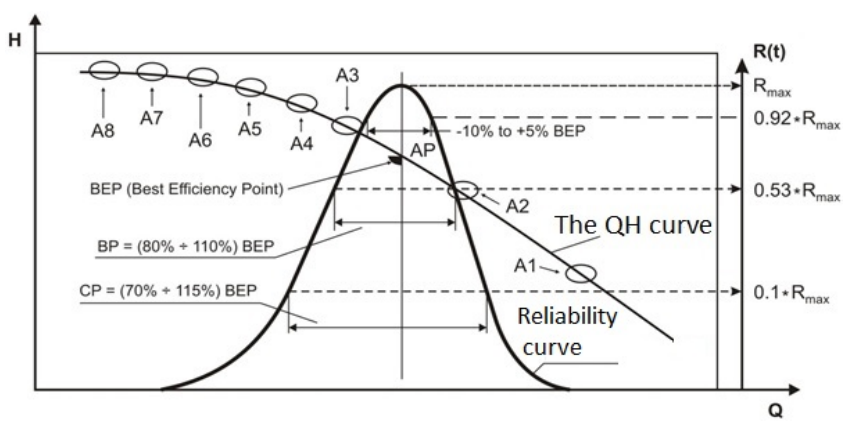

Figure 3. Distribution of pump operation reliability characteristics as a function of efficiency: A1 - cavitation, A2 - shorter life of bearings and sealings, A3 - eddy currents in the discharge part, A4 - eddy currents in the suction part, A5 - shorter life of rotor, A6 - shorter life of bearings and sealings, A7 - cavitation for low flows, A8 -temperature growth $[1,2]$

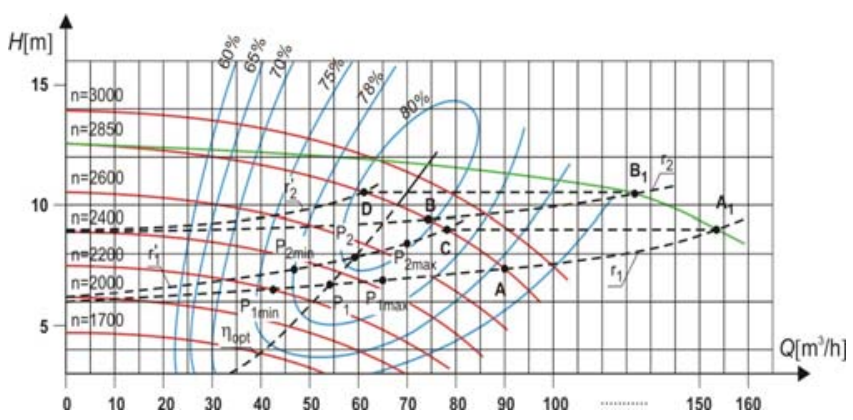

Figure 4. Analysis of sewage pumping station's operation based on any pump performance chart [17]

Authors proposed the comparative analysis of pumping station properties for a cascade control system and by varying rotational speed based on the pump's performance chart (Fig. 4). The pump is assumed to raise sewage level (the head of sewage) in the storage tank by $3[\mathrm{~m}]$. For a maximum tank filling, properties of the pumping system are determined by the characteristic $r_{1}$, while for the minimum level, by the curve $r_{2}$. For the purposes of comparative analysis of pumping station properties under the above assumptions, the following variation ranges were adopted:

- Of pump efficiency $\eta$,

- Of pump capacity $Q$ relative to its optimum value $Q_{\text {opt; }}$ effect of capacity on the pump operation reliability was adopted as the criterion (Fig. 3). In practice, pump capacity should be in the following range:

$Q \in(0,8 \div 1,2) Q_{\text {opt }}$

For capacity below $0.8 Q_{\text {opt }}$ there is a probability of occurrence eddy currents in the discharge part. In contrast, for capacity greater than $1.2 \mathrm{Q}_{\mathrm{opt}}$, the probability of shorter life of bearings and sealings increases. At the same time, for the designated operating capacity range of the pump, the highest pump efficiency values are expected. Adopting a smaller range of pump capacity changes will reduce the pump efficiency range. However, this can cause the pump to be switched on and off too often due to the lack of equality between incoming sewage and pump capacity. 
In cascade control, the pump's operating point is along the flow characteristic for the rotational speed $n_{N}=2850$ [rpm]. As the sewage level shifts by 3 [m], the pump operation is between A and B. Figure 4 produces the following variation ranges:

- Of capacity $Q_{A B} \in\left(Q_{A} \div Q_{B}\right) \approx(1,1 \div 1,39) Q_{\text {opt }}$,

- Of pump efficiency $\eta_{A B} \in(72 \% \div 81 \%)$.

The resultant range of efficiency variations can be regarded as insignificant and acceptable in applications. Capacity, on the other hand, exceeds the maximum acceptable value by approximately $0.2 Q_{\text {opt }}$. The range of efficiency $Q_{A B}$ variations proves a pump is liable to cavitation. It causes faster rotor wear, reduces pump efficiency, and requires its premature overhaul.

In cascade control of two pumps, a pumping station operates along the summary station flow characteristic between $A_{1}$ and $B_{1}$. Operation of a single pump can be analysed on shifting $A_{1}$ to $C$ and $B_{1}$ to $D$ on the flow characteristic of a single pump. Point $C$ is located on an apparent characteristic $r_{1}{ }^{\prime}$ that relates to the real characteristic of the pumping system $r_{1}$ as a result of $A_{1}$ shifting to $C$. In parallel, point $\mathrm{D}$ is located on an apparent characteristic $r_{2}{ }^{\prime}$ that relates to the real characteristic of the pumping system $r_{2}$. The following variation ranges are derived from Figure 4:

- Of capacity $Q_{C D} \in(0,9 \div 1,16) Q_{\text {op }}$

- Of pump efficiency $\eta_{C D} \in(79 \% \div 82 \%)$.

Pumping station operation under cascade control and given these assumptions is energetically effective and fulfils the criterion of high reliability when operating at the rated operational speed. This analysis leads to the following conclusions:

- Where one pump is in operation, it may be overhauled early due to cavitation,

- Two pumps in operation reach high values of efficiency and reliability,

- Operation of one or two pumps exhibits increased losses in a control system maintaining a steady maximum - level of sewage that corresponds to the pumping system characteristic $r_{1}$.

A single pump operates at a variable rotational speed and maximum sewage level along the pumping system characteristic $r_{1}$. Point $\mathrm{P}_{1}$ is assumed to be located on the similarity parabola of optimum efficiency $\eta_{\text {opt. }}$ This operation point ensures maximum pump efficiency for a given head. It is also assumed to correspond to capacity $Q P_{1}$, named optimum capacity as a maximum efficiency out of the set of all efficiencies in the characteristic $r_{1}$ is reached at this point. In line with (3), the range of pump capacity variations at a maximum sewage level may be assumed to be in the range:

$$
Q \in\left(Q P_{1 \text { min }} \div Q P_{1 \max }\right) \approx(0,8 \div 1,2) Q P_{1}
$$

The foregoing argument includes a simplification that points $\mathrm{P}_{1 \min }, \mathrm{P}_{1}, \mathrm{P}_{1 \max }$ should be situated on the same flow characteristic corresponding to one rotational speed. This is not of paramount importance from a practical point of view, since boundary capacity values are assumed with a tolerance of $\pm 0.05 Q_{\text {opt }}$ for which a high pump reliability is assured (Fig. 3).
Two pumps operate at a variable rotational speed and maximum sewage level along an apparent pumping system characteristic $r_{1}{ }^{\prime} . P_{2}$ is on the similarity parabola of optimum efficiency $\eta_{\text {opt. }}$ Like for the operations point $P_{1}$, the range of pump capacity is in the range:

$$
Q \in\left(Q P_{2 \min } \div Q P_{2 \max }\right) \approx(0,8 \div 1,2) Q P_{2}
$$

The above analysis implies conclusions comparing impact of a control system on pump operation. For control by varying rotational speed:

- A high pump operation capacity is preserved with an extensive range $\left(\Delta Q=0.4 Q_{\text {opt }}\right)$ of pump productivity variations,

- Pump operation is near its optimum values,

- Losses associated with an unreasonable head of pump and the resultant losses, defined with the factor $\mathrm{Hf}_{2}$ control quality for cascade regulation $\zeta_{\text {kas }}=1-\frac{H_{2}}{H_{2}^{*}}$, are ignored.

In the case of cascade control:

- High efficiency values for the entire range of pumping station capacity are not required,

- Cavitation is very likely, connected with unreasonable head of pump relative to the pump system characteristic $r_{1}$

The adopted range of capacity variations for one and two pumps operating at a variable rotational speed should provide for a balance between incoming sewage $Q_{x}$ and pumping station capacity $Q_{0}$ at a maximum level of sewage. Under such a system of operation, fulfillment of the criteria of high energy effectiveness and pump reliability should be expected. Lacking such a balance, the following may be necessary:

- Switch the pumps off temporarily for a low incoming sewage,

- A temporary rise of rotational speed at the expense of pump reliability at times of high incoming sewage (this is relatively rare).

\section{CONCLUSION}

Cascade control is normally used as the simplest application solution. The numbers of combined sewage pumping stations require application of variable rotational speed control. Minimising energy consumption and limitation of water hammers in sewage systems are the overarching objectives of this control.

The methods for controlling the operation of pump sets are to control the output parameters of the pump, e.g. the pump head. The authors assume that there is a possibility of controlling the level of sewage head at the pump suction. The increase of this head should aim to reduce the pump's head. As a result, the energy needed to pump sewage should be minimized. Based on the comparative analysis of the two control systems, the efficiency for cascade control varies from $72 \%$ to $82 \%$. At the same time there is an additional pump system losses. The authors assume that in the case of a pump with variable speed, the inflow of 
sewage into the tank is the same as its outflow. The level of sewage will be set at such a height that the pump works with optimum efficiency. The analysis shows that the pump operates at point P1 and the efficiency is constant and amounts to $79 \%$. An additional benefit of the proposed control system is the extension of the reliability operation period of the pump.

The proposed solution is more expensive than cascade control. A new or modernised pumping station can utilise a new control system if incoming sewage is steady, which will bring faster returns on financial outlays. The proposed control system requires further studies to estimate unit energy consumption of the pumping as a function of sewage head variations in the suction manifold.

\section{REFERENCES}

[1] H, P Barringer, "A Life Cycle Cost Summary," in Internatinal Conference of Maintance Societies, Perth, 2003.

[2] H, P Barringer, "Life Cycle Cost and Good Practices," in NPRA Maintance Conference, San Antonio, 1998

[3] S, H Ahmad, "Metoda optymalnego doboru i zmniejszenia kosztów eksploatacji pomp w przepompowniach," Warszawa, 2000

[4] AM Council Body of Knowledge Glossary Project Team, Influencing Lifecycle Cost Though Continous Improvement
[5] J Bagieński, "Efektywność energetyczna układów przetłaczania ścieków," in Problemy zachowania wysokiej efektywnościenergetycznej pomp i systemów pompowych, Grudziądz, 2012

[6] European Commission, "Study on improving energy efficiency of pumps," Brussel, 2001

[7] L Frenning, Pump Life Cycle Costs, a Guide to LCC Analysis for Pumping Systems.: Hydraulic Institute, 2001

[8] K Gradkowski, "System urządzeń kontroli spływu wód opadowych w obszarze węzła drogowego," Drogownictwo, no. 8, 2009

[9] J, F Gulich, Centrifugal Pumps. London: Springer, 2010

[10] W Jędral, Pompy wirowe. Warszawa: PWN, 2001

[11] W Jędral, "Zmiana sprawności pompy wirowej przy zmianie jej prędkości pobrotowej," in Problemy Enegetyki Cieplnej., 1999

[12] LFP Leszczyńska Fabryka Pomp, "Przepompownie ścieków PS," 2012

[13] R Mazurkiewicz, "Odwodnienie stacyjnych torów przyperonowych," in Nowoczesne technologie w realizacji projektów inwestycyjnych transportu kolejowego, Jurata, 6-8 V 2008

[14] N Smith, Highway stormwater pump station design. Virginia: U.S. Department of Tranportation, 2001.

[15] L Szychta, "Pump assembly optimum control," in 11 International Power Electronics and Motion Control Conference EPE-PEMC, Riga, 2004.

[16] L Szychta, "System for optymising pump station control part I, part II," World Pumps, Feb 2004

[17] L.Szychta, "Pompownie w systemach odwadniania infrastruktury kolejowej', Radom, 2012 